This is an electronic reprint of the original article. This reprint may differ from the original in pagination and typographic detail.

Author(s): Ojala, Arto; Heikkilä, Jukka

Title: $\quad$ Entrepreneurship training for new ventures

Year: $\quad 2010$

Version:

Please cite the original version:

Ojala, A., \& Heikkilä, J. (2010). Entrepreneurship training for new ventures. International Entrepreneurship and Management Journal. https://doi.org/10.1007/s11365-009-0126-3

All material supplied via JYX is protected by copyright and other intellectual property rights, and duplication or sale of all or part of any of the repository collections is not permitted, except that material may be duplicated by you for your research use or educational purposes in electronic or print form. You must obtain permission for any other use. Electronic or print copies may not be offered, whether for sale or otherwise to anyone who is not an authorised user. 


\title{
Entrepreneurship training for new ventures
}

\author{
Arto Ojala and Jukka Heikkilä \\ University of Jyväskylä
}

\begin{abstract}
Several studies in the field of international entrepreneurship have indicated the inadequacy of public policy support for new ventures and called for more tailored training programs. This paper introduces a training program created for new ventures in Central Finland and analyzes its benefits and shortcomings using a qualitative case study. The findings reveal that the training program provided useful knowledge on how to develop a business further and how to make it understandable and attractive to a funder. However, the findings also indicate that there is a need for cultural adaptation: the training program developed originally for U.S. new ventures was not fully adapted for the needs of Finnish entrepreneurs. The program mainly focused on risk taking, raising funds from capital markets in the U.S., and entering into the U.S market soon after the establishment. This was in contrast to the Finnish entrepreneurs' strategies: they preferred to grow their business in a more controlled and profitable manner. Thus, although knowledge-intensive new ventures operate in global environments, the training provided for them should take into account the cultural differences and the local way of doing business.
\end{abstract}

Keywords: Entrepreneurship training, new ventures, international entrepreneurship, small firms, Finland 


\section{Introduction}

Research related to rapidly internationalizing, knowledge-intensive SMEs has been of increasing interest since 1990s. These firms, known as "international new ventures" (INVs) or "born globals" seek for growth opportunities and resources in international markets very early on in their life-cycle (Bell et al. 2003; Oviatt and McDougall 1994). This phenomenon has also been boosted by the rapid expansion of global venture capital funding in the millennium shift (see e.g., Green 2004).

As it is commonly known, these kinds of firms are very beneficial to the local economy as they create most of new jobs, open new market sectors, and develop new products and services. For instance, in the OECD countries, over 95 percent of all firms are SMEs and they employ 60 - 70 percent of workforce (OECD 2000). These SMEs are increasingly becoming involved in technology-intensive industries to reach for global markets with their innovative products. However, there are also many constraints that might hinder or even prevent small firms in their attempts to reach the opportunities available for them in foreign markets. These include, for instance, the lack of financial and human resources and skills needed in their local services. For these reasons, researchers have called for more tailored institutional support and training to facilitate the growth of small and innovative new ventures (Bell 1997; Bell et al. 2003, 2004; Crick and Spence 2005; Dimitratos and Jones 2003; Rialp et al. 2005; Spence 2003). In Central Finland, we answered to this request by implementing a training program for our local growth- 
oriented, technology-based new ventures. The program was arranged once a year between 2005 and 2007. Its main purpose was to improve entrepreneurs' preparedness for international business already in their early years of existence. Because the field of international entrepreneurship is still very new and emerging, there are few studies focusing on what kind of training the local business incubation environment should offer for new ventures in knowledge-intensive sectors. The aim of this paper is to analyze the benefits and shortcomings of the training program implemented in Central Finland and to suggest further directions for entrepreneurship training for high-technology new ventures.

\section{Internationalization of new ventures}

In the late 1980s, researchers (e.g., Ganitsky 1989; McDougall 1989) started to observe the increasing number of rapidly internationalizing newly established ventures. Development of communication and transportation channels, homogenization of markets, and increasing international and cultural awareness have served as accelerating forces to this phenomenon (Autio 2005; Oviatt and McDougall 1994, 2005). In recent years, a number of researchers have also concluded that the internationalization behavior of these rapidly internationalizing new ventures does not follow the traditional internationalization theories, such as the Uppsala model (Johanson and Vahlne 1977; Johanson and Wiedersheim-Paul 1975). The study of Oviatt and McDougall (1994) was among the first ones that gave a theoretical foundation for why these kinds of firms exist in international markets. The INV theory proposes that the internationalization behavior of these firms is opportunity seeking where a new venture “...seeks to derive significant 
competitive advantage from the use of resources and the sale of outputs in multiple countries" (Oviatt and McDougall 1994, 49). The theory is motivated by the observation that INVs' origins are international because they have commitments to valuable resources in more than one country, for instance through their networks. They can also take advantage of modern information and communication technologies (e.g., groupware, webinars, and digital distribution of updates and content) in their operations. In the theory dubbed "international from the inception" it is conceptualized that the founders of an INV seek for growth opportunities in several foreign markets already before their formal foundation. Thus, entrepreneurs of these firms have made some decisions related to the international scope of the activities before the formal establishment of their firm (McDougall et al. 1994; Oviatt and McDougall 1994). The main difference between incremental internationalization theories, such as the Uppsala model and the INV theory, is that the INV theory suggests that firms can skip stages or not have any stages at all in the internationalization process (Oviatt and McDougall 1994). Empirical studies related to knowledge-intensive INVs have found that these firms enter the leading markets in a very early phase (Ojala and Tyrväinen 2007a), use several entry modes (Coviello and Munro 1997; Ojala 2008), and various network relationships to facilitate their internationalization (Coviello 2006). However, current studies have generally focused only on those firms which have been very successful in their internationalization while problems and constraints for rapid internationalization have received much less attention. 


\section{Problems related to start-up and internationalization}

Studies focusing on start-up and growth problems of new ventures have shown that most of the problems are related to sales and marketing, obtaining external funding, and financial management (Kazanjian 1988; Terpstra and Olson 1993). Entrepreneurs of new ventures might also have a great, promising idea but they often lack commercial skills and business experience (OECD 2000), especially in the early stages of development. The study of Sapienza et al. (2006) suggests that firm's age, managerial experience, and resource fungibility moderates INVs internationalization, survival, and growth. The study of Bell (1997) related to small software firms' export problems indicates that financial and marketing issues were notable constraints for international expansion of these firms. The five most cited problems were, in detail: delays in payment, price competitiveness, communication with customers, obtaining export finance, and currency fluctuation. The study also revealed that communication problems were finance-related, as well, because visiting customers and requirements of face-to-face communication, in terms of installing and after-sales services, were needed in that context (Bell 1997). In their study related to software SMEs' entry barriers in the Japanese market, Ojala and Tyrväinen (2007b) found that most of the entry barriers could be associated to the firm's internal factors and the sales process. These factors included communication problems, recruitment of capable employees, and finding of right contact persons. The study of Freeman et al. (2006) divides the constraints of rapid internationalization of INVs into three main areas:

poor access to economies of scale, lack of financial and knowledge resources, and 
aversion to risk taking. In addition, they indicate how these firms can use alliances and network relationships to overcome these constraints. Other studies point out that in many cases a component of the local business incubation environment, such as industrial clusters' support, has been considered of high importance (Gilbert et al. 2008; Porter 1998).

As discussed above, new ventures can encounter a number of problems in their early phases of growth and internationalization. Thus, there seems to be a demand for specific support programs for this kind of rapidly internationalizing, technology based new ventures. However, several studies (Bell 1997; Spence 2003) have indicated the insufficiency of the support provided, for instance by national, or regional export promotion organizations (EPOs). For this reason, several studies have called for more specific and tailored training programs for new ventures (Bell 1997; Bell et al. 2003, 2004; Crick and Spence 2005; Dimitratos and Jones 2003; Rialp et al. 2005; Spence 2003). The main criticism towards the public policy support for new ventures has been related to a very general level of market information provided by government based organizations. This information is nowadays publicly available and it is seldom the kind of information that is to the benefit of the new growth ventures in their specific, practical problems. The study of Bell et al. (2003) indicates also that EPOs support is commonly targeted toward traditional firms applying an incremental internationalization process and that this kind of support does not benefit rapidly internationalizing new ventures. In their later study, Bell et al. (2004) suggest that because these firms develop their operations much more dynamically compared to traditional firms, the support should be immediate 
and it should be provided in a very early phase. The authors also highlight the importance of management training, strategic issues, help with inward technology transfer, and development of network relationships with larger firms (Bell et al. 2004). Requirements for assistance with networking to get access and recognize important networks available in foreign markets is indicated in several studies (Bell 1997; Bell et al. 2003; Crick and Spence 2005; Ojala 2009; Spence 2003). As suggested in the study of Bell (1997), networking should be the focus of visits for clients and potential customers at trade fairs, to increase the number of face-to-face contacts in new ventures. In this case, EPOs can also be very helpful, especially if a firm is entering distant, unknown markets (Ojala 2009).

It may be concluded therefore that EPOs support for new ventures has been insufficient due to new ventures' specific needs. In addition, rapidly internationalizing new ventures are a rather new phenomenon, and EPOs have not been able to answer their needs for meeting the requirements of high growth targets set by venture capitalists. In reward for the risk capital allocation, a venture capitalist typically sets high growth targets for each product/market segment. This puts a high pressure on the general management, personnel management, new offerings, and business network expansion. If we compare this with the previous incremental, profit-based growth strategy, it is easy to see that they are on a different ballpark, and not understood very well by EPOs or local support environments. On the other hand, knowledge-intensive new ventures present only one segment of firms that EPOs are supporting. Thus, from EPOs' point of view, the question of how much resources and support they can allocate for new ventures involves always a trade-off. 
However, as suggested in the study of Bell et al. (2003), collaboration between EPOs, other public bodies, and academy would be beneficial in providing support for new ventures. Still, local educational institutions are, in many cases, unable to offer relevant and up-to-date training.

\section{Overview of the training program provided for new ventures in Central Finland}

The main purpose of the training program was to provide "timely, relevant, and pedagogically sound training" for high-technology new ventures that have a business idea based on innovative technology, to prepare them for venture capital-rounds. The program evolved in three stages: The first, the trial stage, started in 1998 and ended in 2001 along the dotcom boom. The revised, second and more hands-on stage was implemented between 2002 and 2004. During these early stages it gradually developed to its present, well-established format starting in 2005 in co-operation with the local higher education institutes, a science park and firms. Next, we present the background of the program in detail: how it developed to the current format, and how the program was implemented and structured.

\section{Background and development of the training program}

The first training program was initiated by regional science parks. It was directed towards new ventures in software business with the main objective of 'going global', especially in its strive to establish business in the U.S. It consisted of a series of seminars (mostly 
lectures and assignments, the latter in connection with a couple of dedicated consultancy days during the seminars). It was directed towards increasing knowledge of the world's largest high-tech market, the U.S. A number of experienced U.S. and Finnish international software entrepreneurs and venture capitalists conducted the program. At the first stage, engaging the local university and polytechnic into co-operation failed. This was because of a simultaneous overwhelming increase in graduate student intake on the potential key areas and friction between different faculties within the university. In addition, the local polytechnic resources were not up to the task in the first place: poor language skills as well as lack of new venture practice and lack of experience in business teaching were some of the critical areas, to name a few. Because of the novelty and little research conducted in the field, both institutions were also suffering from meager resources and expertise.

In the second stage, the initial program was split in two related activities: a short annual pre-seminar about the markets and a more in-depth, spin-off education program on how to prepare for venture capital funding rounds. The second stage was based on a U.S. consultant's concept for education. The consultant was willing to tailor it to the situation at hand. The local arrangements were now a cooperative effort of the university, the polytechnic (which had experienced a significant improvement in its resources), and the science park funding the co-operation and helping in finding potential companies. The university hired an entrepreneur to manage the program. He had taken his firm from the start-up to initial public offering, so eventually there was a person with practical experience in place. He restructured the program to make it a project, where the students 
were used as a resource for the entrepreneurs, and brought in some more experienced entrepreneurs to evaluate the outcome of the courses. He also introduced and added some other parts that went beyond the original scope, and introduced a number of his friends from the business to the program. Unfortunately, he unexpectedly left the program, leaving it drifting.

\section{Implementation and structure of the final training program}

In the third stage, the management structure of the project was clarified to facilitate cooperation for developing the program in line with long-term objectives. In practice, the institutions became responsible for gathering feedback, planning and implementing the necessary changes. A formal steering group of institutions' representatives was established to follow the implementation of the improvements based on the feedback. The program made more systematic use of the feedback from the participants and of the latest knowledge in new venture education. In retrospect, even more important was the establishment of a round-table of actors from the three parties. As a consequence, the actors were able to gain a shared understanding and could align the program objectives to meet the clientele requirements in short notice. The round table played a major role in setting directions and keeping up the spirits among the participating institutions, while the steering group kept track of the detailed, actual implementation led by the coordinator. 
During the ten-week program, entrepreneurs got business planning advice and hands-on training to reformulate their business idea further - typically from a service idea to a fullfledged product offering. This aimed at meeting venture capitalists standards on business idea presentation, business plan, and financial calculi. Participants came from various fields of technology business. Most of the business ideas were related, but not limited, to software for enterprise solutions, role playing games, learning games, and content management. The rest were related to welfare technology, chemistry, merger and acquisitions services, and research business.

Students from the local university and polytechnic were brought into the program so that each entrepreneur got two to three students to work on the entrepreneur's business idea. Students worked closely with entrepreneurs and helped them to develop and refine the business plans and the final presentation. As a positive side effect, many of the students got a position in these firms. As a consequence, the program started to attract hardworking, motivated students, especially as it was included partly in the curriculum. The training program had eight modules:

1. Introduction and Strategic Planning

2. Technologies, Intellectual Property, and Product Portfolio Roadmapping

3. Marketing and Sales Plans

4. Competition

5. Operations, Management, and Staffing

6. Financial Plans 


\section{Training for Presentation}

\section{Final Presentations}

In practice, the program was run in the following manner: two- to three-hour lectures were arranged for all participants (including students) based on the topic of each module. After each lecture, there were individual face-to-face mentoring sessions and those lasted about one hour each. In these sessions, coaches, invited experts, and students went through the issues related to the module's topic in the context of the entrepreneur's business. Each module included also 'home assignments', which were discussed and revised in mentoring sessions. In addition, the aim of the mentoring sessions was also to ensure the progress towards the 15-minute final presentation for investors. In the final presentation, each entrepreneur presented his/her finalized business plan to a panel including coaches, mentors, investors, external experts, professors, etc. After the 15minute presentation, the entrepreneur in question got feedback on the presentation and business plan. The feedback made it possible for the entrepreneurs to develop their presentation and business plans further. In addition, some of the most promising business plans got seed funding from the investors.

To summarize, the final training program was implemented around the core created by the U.S. consultant and managed and coordinated by a steering group consisting of one representative from all parties, then guided with a consensus and delicate feedback from all the actors. Basically, the program followed an inter-subjective co-constructive educational genre by triangulating and learning-by-doing business and financial planning. 


\section{Methodology}

The qualitative multi-case study method was selected for this study. As Yin (1994) indicates, the multiple case study method enables explaining the significance and causeand-effect relationships of the phenomena under investigation. Thus, it enabled gathering more detailed information about the case firms investigated and about the effects of the training program for their business activities.

The case firms were selected as advised in Eisenhardt (1989). The selected firms participated in the training program implemented, and they had a reasonable business idea about how to expand their business into international markets. In other words, they were seeking for business opportunities from foreign markets very early in their life-cycle (Oviatt and McDougall 1994). In addition, all the firms (except Firm B) were already, to some extent, involved in international business through their outward and/or inward activities. Table 1 gives the basic information of the case firms investigated. As shown in Table 1, Firm $\mathrm{C}$ was still at the idea stage and not formally established at the time of the interviews. We conducted semi-structured open-ended interviews with each firms' founder or managing director who attended the training program. All the interviews, lasting 40-60 minutes, were digitally recorded and transcribed by a word processor. We conducted a second listening to ensure correspondence between the recorded and written data. After that, we sent the written case reports back to the entrepreneurs interviewed to 
ensure the validity and authenticity of the collected data. If the entrepreneurs interviewed found inaccuracies in the text, we corrected these based on their comments. When necessary, we also acquired additional data afterwards by telephone and email to avoid possible misunderstandings and inconsistencies in the collected data.

In the data analysis, we followed the guidelines suggested by Eisenhardt (1989) and Yin (1994). First we wrote all six individual cases as stand-alone case descriptions. After that, we identified the unique patterns based on the main interview questions in the each case and, thereafter, categorized similar patterns under common themes. These themes included topics such as benefits of the training program, shortcomings, and further training needs. This helped to organize and summarize the collected data.

\begin{tabular}{lccc}
\hline & $\begin{array}{c}\text { Year of } \\
\text { establishment }\end{array}$ & Number of employees & Field of business \\
\hline Firm A & 2005 & 5 & Digital media \\
Firm B & 2006 & 10 & ICT-project management \\
Firm C & Not formally established yet & 2 & Wireless network systems \\
Firm D & 2005 & 7 & Life science technology \\
Firm E & 2007 & 9 & Digital media \\
Firm F & 2003 & 4 & Life science technology
\end{tabular}

Table 1. Key information on the case firms.

\section{Case findings}

This chapter presents the case findings divided into three categories. In Table 2, the first column shows the issues that the case firms stated as important benefits learned in the program. The second column presents shortcomings and critiques toward the program. 
The third column shows the further training needs highlighted by the case firms. The end of the chapter elaborates on these in more detail.

Table 2. Overview of the case findings

Benefits of the training program Shortcomings / critique related to the $\begin{gathered}\text { Further training needs } \\ \text { training program }\end{gathered}$

- Getting a general view of the business

- Organization of ideas

- Articulation and presentation of own business idea

- Understanding own business potential

- Critical thinking

- International marketing skills

- Understanding venture capital

- Acquisition of risk money

- Individual guidance

- Networking with other entrepreneurs and students
- U.S. based business attitude neither applicable to the realm nor to the foreign market of the companies

- Focus solely on venture capital funding, other sources not included

- Focus on product business. Service business was considered as an interim stage

- Too general: practical issues and day-to-day problems were missing
- More practical training

- Business Networking

- Market / country related information

- Information related to controlled growth

- Information about funding sources in Finland

2nd


Most of the entrepreneurs had a technical education and they lacked strategic business skills needed to get their business idea further. The program helped them to organize their thinking and to structure their business idea in a better way. Communicating a business idea to non-technical persons was also difficult in the beginning but with the help of the program, entrepreneurs learned to express themselves and to articulate about their business better for their customers, partners, and venture capitalists. The entrepreneur from Firm F explained this in the following manner:

"...it helped to understand how to communicate in such a way that also others understand it. Although there are good ideas, they can be expressed in such a funny way that no one can understand what is going on. So we practiced hard with the presentation technique; it was our biggest challenge at that moment"

Entrepreneurs also mentioned that the training program helped them to understand their business potential better from both technical and business point of views. It helped them to evaluate who the potential customers are worldwide and how the technology should be planned and protected for the demands of international markets. These entrepreneurs also indicated that the training program helped them with critical thinking, meaning that after the program they had knowledge about how to evaluate their products and business ideas potential for international markets. This was also related to international marketing skills, how to network with other actors in international markets and how to market their products to potential customers. The entrepreneur from Firm $\mathrm{C}$ expressed this as follows: 
"It gave a deep impetus to see the potential, not only from the technological side but also from the business side. How to create such a strong basis [for the business] and how to regard it so that others will see it as well, such as banks, venture capitalists, and other partners"

Because the program focused heavily on the acquisition of risk money from venture capitalists, it was seen as being helpful in cases where a firm was planning to get risk funding, especially from the U.S. market. In the training program, the mentoring sessions were also regarded as very helpful, because there the entrepreneurs got individual feedback from experts about their progress and comments on how to develop their ideas further. Networking with other participating entrepreneurs and students were also mentioned as being very helpful. Some firms got customers from or made partners with other participants, and some firms' recruited participating students to work in their firms. Thus, the program served also as a recruitment channel for the firms.

\section{Shortcomings and critique toward the training program}

Almost all firms regarded the training program as being too much based on the U.S. business culture and a type of attitude that was not fully adapted to the Finnish business culture. The training program focused heavily on early phase internationalization to the U.S. market and on seeking venture capital from there. The general opinion was that although the risk money is more easily available in the U.S. than in Finland, to get it is too demanding for Finnish firms. Another opinion was that the U.S. firms have more 
opportunities to grow their business in their home country before internationalizing to other markets. In contrast, Finnish firms have to internationalize earlier and with limited resources, and, thus, their internationalization, being risky, is more restrained. Thus, speaking about big risk investments was seen to be very confusing and even provocative. This might also be related to differences in the business attitude between the U.S. and Finland: the U.S. business culture is more risk seeking compared to the Finnish business culture based on controlled growth. In addition, first markets for the firms products were expected to be, many times, rather different from what the U.S. market and business culture represent. The entrepreneur at Firm D emphasized this as follows:

"We are here in Scandinavia, in Europe, that is to say, it [the training program] focused too much on the U.S., meaning too early to large markets and too big a picture... They spoke about billions [dollars]...that is utopia, it is not possible here... you need to have a really big case that you can go to the U.S. and speak about hundreds of millions with venture capitalists as an investment"

The entrepreneur from Firm A had also a very similar opinion. He commented this in the following manner:

"They spoke about billions [of dollars] even when one hundred thousand would have been a really big thing for us in the beginning...it really annoyed us...they also said that we should get the best lawyer from New York, it was a [beep], no one from Finland went along with this." 
The approach taken in the training program was also seen as oriented too much towards products; many of the attending firms were in the service business or an important part of their business was related to services. Those firms that had more to do with the service business side experienced this as very confusing, as they felt that their service business still had significant growth potential in domestic and neighboring markets. And this was also in contrast to the everyday experience of very profitable consulting and b-to-b services, as the entrepreneur from Firm B underlined by stating:

"We are not Microsoft selling in millions; however, we still have a full potential to grow reasonably in the nearby markets that will show a profit for us and our shareholders. They did not support this kind of thinking at all..."

Although the training program met very well the needs of product-based new ventures, entrepreneurs stressed that practical issues and the Finnish perspective to business were elements that were missing. Entrepreneurs would have liked to be provided with practical help for day-to-day problems, such as taxation, accounting, etc. However, the program was too short for that: it could not go into very detailed issues, and its main objective was quickly readying the entrepreneur for selling the business idea to potential stakeholders in the well-established and proven U.S. way.

In addition, the program focused on getting prepared for venture capital rounds, and the other funding sources were not included. Thus, there was a lack of information about other funding possibilities for their business. This was seen to be a significant weakness, 
because many of the entrepreneurs felt that getting funding from venture capitalists would be too demanding and they did not want to give the control of their firm to venture capitalists. The entrepreneurs also emphasized that venture capital is not that easily available in Finland, especially for their markets, and that there are also other sources to obtain funding, with less stringent requirements attached.

\section{Further training needs}

All the case firms agreed that the program gave a very good idea of the high-tech business from a general point of view. However, they announced that in the future they would need more in-depth and detailed training about day-to-day issues. The specific further training needs were related to marketing, financial issues, tax counseling, problem solving, etc, because the entrepreneurs considered these as the key drivers of the bottom line. Networking opportunities with other entrepreneurs and students during the program were seen as very helpful. For this reason, entrepreneurs would like to have these kinds of networking opportunities also in the future to share their experiences and build new networks with other entrepreneurs and students. One aspect that was missing from the training program was information about some particular foreign markets, because the program focused mainly on the U.S. market. For instance, the entrepreneur from Firm A stated that information about specific markets would be beneficial to understand the requirements for market entry and how to conduct business there. Because the training program focused on the acquisition of venture capital, mainly from the U.S. venture capital markets, the entrepreneurs stated that more information about funding sources in 
Finland would be needed in the future. Information about controlled growth was also called for, because the program focused solely on fast growth with venture capital.

\section{Discussion and conclusions}

This paper presented the evolution and an assessment of a training program for new ventures implemented in Central Finland. The program can be classified as a cocreationary constructive program where learning-by-doing is supported with intersubjective triangulation and reflection. We wanted to know whether the favorable remarks about the program when it was initiated were still considered valid by the practicing entrepreneurs after a few years and whether some corresponding programs in the future could be arranged better.

Although the case firms had been recently established and had relatively few employees, they were already involved in international business and/or were actively searching new opportunities from foreign markets. Thus, these firms correspond to similar firms, described as INVs or born-globals, in the studies of Oviatt and McDougall (1994) and Bell et al. (2003). In all the firms, technological knowledge of entrepreneurs was at a very high level. However, their business skills were behind their technical skills. In line with earlier studies observing new ventures' growth and internationalization (Bell 1997; Freeman et al. 2006; Kazanjian 1988; OECD 2000; Terpstra and Olson, 1993), the firms had needs to develop their business skills related to marketing, communication, and financial issues. 
The purpose of the program was to provide tailored training for new ventures, as called for in several studies (see e.g., Bell et al. 2003; Spence 2003). As the findings indicate, all the firms benefited from the program and got knowledge about how to develop their business further. In addition, they were able to develop their network relationships during the program with various actors from the industry, university, science park, etc. As indicated in the study of Coviello (2006), these kinds of networked relationships are very important already in the early phase of new ventures' life-cycle impacting positively their further growth and internationalization. However, the feedback also indicates that the U.S. practices of doing business were not within the daily realm of the entrepreneurs. First of all, quick funding seemed a foreign concept for the entrepreneurs who were still in the mindset of developing their concept towards a profitable product. Thus, the findings indicate very clearly that the training program developed in the U.S. was not as such fully adapted for the needs of Finnish entrepreneurs. We can argue that the main reasons for this were cultural differences and different views about how to grow business. The training program focused too much on risk taking and venture capital markets in the U.S., whereas the Finnish entrepreneurs who attended liked to grow their business in a more controlled and profitable manner. Although the firms represented so called "global industries", the Finnish cultural values about how to grow business differed greatly from the U.S. style. In addition, many of these firms have a service based business idea where the availability (in reality) of huge growth funds is not probable. This means that they prefer to learn from those factors that affect the business in a systemic predictable way, avoiding overly bold plans that are not realizable within their limited resources. 
We also observed that the entrepreneurs were driven by the urge to achieve something in order to make a contribution towards the society, not 'just to make money'. For instance, they resisted the idea of giving their business away to venture capitalists, and, ultimately, they have the choice, especially with novel ideas. Furthermore, the entrepreneurs were not entirely comfortable with straightforward guidelines from another context, but wanted to construct their knowledge by themselves, challenging and questioning the things to be learned. The format of the course actually moved to that direction: an indication of this was that the business ballpark outlook became separated from the more constructive, assignment-driven latter part. However, the findings indicate that even more tailored training programs for new ventures are needed. Nevertheless, this calls for intensive and extensive co-operation and willingness to modify an already winning concept, as was the case in this program.

We hope that the findings presented in this paper help universities and other training institutions to develop their corresponding programs further. As indicated in several studies (Bell et al. 2003; Crick and Spence 2005; Dimitratos and Jones 2003; Spence 2003), new ventures in technology-intensive sectors certainly need this kind of training programs to develop their business skills for international markets. Although the feedback from the program was generally very good, we also received very important critique. Based on this, the future programs can avoid the gaps pointed out. The main lesson learned here was the fact that although entrepreneurs were operating in global environments, the training provided for them should take into account the local way of 
doing business. Thus, although international and cultural awareness is nowadays greater than ever (Autio 2005), cultural values about how to grow and manage business seem to be very deep-rooted (see e.g., Hofstede 2001; Leana and Barry 2000) and should be taken into account when implementing corresponding training programs for new ventures. By first recognizing local entrepreneurs' values and expectations, training programs can be directed towards them in such a manner that they won't underestimate their business potential or get confused with exaggerated promises. By expanding the idea of Bell et al. (2003) proposing that collaboration between EPOs, other public bodies, and academy would be beneficial for new ventures, we suggest that there is a need for international collaboration between all these parties in different countries. In that way, an international platform on entrepreneurship training for new ventures can be created. As a consequence, local business and training knowledge from several countries can be shared in international networks for the benefit of all parties.

\section{References}

Autio E (2005) Creative tension: the significance of Ben Oviatt's and Patricia McDougall's article 'toward a theory of international new ventures'. Journal of International Business Studies 36(1): 9-19.

Bell J (1997) A Comparative Study of the Export Problems of Small Computer Software Exporters in Finland, Ireland and Norway. International Business Review 6(6): 585604. 
Bell J, McNaughton R, Young S, Crick D (2003) Towards an Integrative Model of Small Firm Internationalisation. Journal of International Entrepreneurship 1(4): 339-362.

Bell J, Crick D, Young S (2004) Small Firm Internationalization and Business Strategy. International Small Business Journal 22(1): 23-55.

Crick D, Spence M (2005) The internationalisation of 'high performing' UK high-tech SMEs: a study of planned and unplanned strategies. International Business Review 14(2): 167-185.

Coviello N (2006) The network dynamics of international new ventures. Journal of International Business Studies 37(5): 713-731.

Coviello N, Munro H (1997) Network Relationships and the Internationalisation Process of Small Software Firms. International Business Review 6(4): 361-386.

Dimitratos P, Jones MV (2003) Public Policy for International Entrepreneurial Small Firms: A Plea for Customised Support Measures. Journal of International Entrepreneurship 1(4): 335-337.

Eisenhardt KM (1989) Building Theories from Case Study Research. Academy of Management Review 14(4): 532-550.

Freeman S, Edwards R, Schroder B (2006) How Smaller Born-Globals Use Networks and Alliances to Overcome Constraints to Rapid Internationalization. Journal of International Marketing 14(3): 33-63.

Ganitsky J (1989) Strategies for Innate and Adoptive Exporters: Lessons from Israel's Case. International Marketing Review 6(5): 50-65. 
Gilbert BA, McDougall PP, Audretsch DB (2008) Clusters, knowledge spillovers and new venture performance: An empirical examination. Journal of Business Venturing 23(4), 405-422.

Green MB (2004) Venture Capital Investment in the United States 1995-2002. The Industrial Geographer 2(1): 2-30.

Hofstede G (2001) Culture’s Consequences. Second edition. New York: Sage.

Johanson J, Vahlne J-E. (1977) The internationalization process of the firm: a model of knowledge development and increasing foreign market commitments. Journal of International Business Studies, 8(1): 23-32.

Johanson J, Wiedersheim-Paul F (1975) The internationalization of the firm: four Swedish cases. Journal of Management Studies 12(3): 305-322.

Kazanjian RK (1988) Relation of dominant problems to stages of growth in technologybased new ventures. Academy of Management Journal 31(2): 257-279.

Leana CR, Barry B (2000) Stability and Change as Simultaneous Experiences in Organization Life. Academy of Management Review 25(4): 753-759.

McDougall PP (1989) International versus local entrepreneurship: New venture strategic behavior and industry structure. Journal of Business Venturing 4(6): 387-400.

McDougall PP, Shane S, Oviatt BM (1994) Explaining the formation of international new ventures: The limits of theories from international business research. Journal of Business Venturing 9(6): 469-487.

OECD (2000) Small and Medium-sized Enterprises: Local Strength, Global Reach, Organisation for Economic Co-operation and Development. OECD Observer, June. 
Ojala A (2008) Entry in a psychically distant market: Finnish small and medium-sized software firms in Japan. European Management Journal 26(2): 135-144.

Ojala, A (2009) Internationalization of knowledge-intensive SMEs: The role of network relationships in the entry to a psychically distant market. International Business Review, 18(1): 50-59.

Ojala A, Tyrväinen P (2007a) Market Entry and Priority of Small and Medium-Sized Enterprises in the Software Industry: An Empirical Analysis of Cultural Distance, Geographical Distance, and Market Size. Journal of International Marketing, 15(3): 123-149.

Ojala A, Tyrväinen P (2007b) Entry Barriers of Small and Medium-Sized Software Firms in the Japanese Market. Thunderbird International Business Review 49(6): 689-705.

Oviatt BM, McDougall PP (1994) Toward a theory of international new ventures. Journal of International Business Studies 25(1): 45-64.

Oviatt BM, McDougall PP (2005) Defining international entrepreneurship and modeling the speed of internationalization. Entrepreneurship Theory and Practice 29(5): 537553.

Porter ME (1998) Clusters and the new economics of competition. Harvard Business Review, 76(6): 77-90.

Rialp A, Rialp J, Knight GA (2005) The phenomenon of early internationalizing firms: what we know after a decade (1993-2003) of scientific inquiry? International Business Review 14(2): 147-166. 
Sapienza HJ, Autio E, George G, Zahra SA (2006) A capabilities perspective on the effects of early internationalization on firm survival and growth. Academy of Management Review 31(4): 914-933.

Spence M (2003) International Strategy Formation in Small Canadian High-Technology Companies: A Case Study Approach. Journal of International Entrepreneurship 1(3): 277-296.

Terpstra DE, Olson PD (1993) Entrepreneurial Start-up and Growth: A Classification of Problems. Entrepreneurship Theory and Practice 17(3): 5-19.

Yin RK (1994) Case Study Research: Design and Methods. California: SAGE Publications. 